International

Center for

Public Policy
International Center for Public Policy

Working Paper 17-21

December 2017

Urban sprawl and local fiscal

burden: analysing the Spanish case

\section{Laura Varela-Candamio}

Fernando Rubiera Morollón

Gohar Sedrakyan

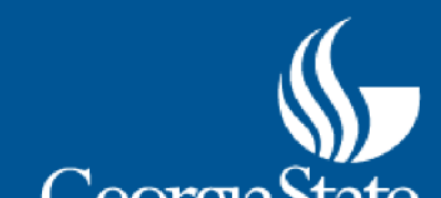

GeorgaState University
ANDREWYOUNG SCHOOL 


\title{
Urban sprawl and local fiscal burden: analysing the Spanish case
}

\author{
Laura Varela-Candamio \\ (C+D Jean Monnet Group \& RIFDE - University of A Coruna, Spain) \\ Fernando Rubiera Morollón \\ (REGIOlab - University of Oviedo, Spain) \\ Gohar Sedrakyan \\ (International Center for Public Policy - Andrew Young School of Policy Studies- \\ Georgia State University, USA)
}

\begin{abstract}
Urban sprawl is rapidly occurring in many Spanish urban areas. The objective of this paper is to evaluate how the trend of building dispersion of new residential areas may be affecting the fiscal stability of local Spanish governments. The high variability of the characteristics of Spanish urban areas as well as the existence of very similar local fiscal structures made this case particularly interesting. A precise index of urban sprawl, calculated with geo-referenced digital cartography, was used. Utilising spatially desegregated information of taxes from the Spanish National Institute for Fiscal Studies allowed for a measure of fiscal burden by local areas and the ability to distinguish among types of taxes. Control variables were also available at the local level from the Spanish Census and other databases. Quantile Regressions methodology supplementing Ordinary Least Square regressions assessed the discrepancy in the results and in the conclusions of the studied distributions. The results indicate that higher levels of urban sprawl imply higher local fiscal burden. This is especially clear in the higher part of the local fiscal burden distribution. By tax categories, the phenomenon of urban sprawl particularly affects local indirect taxation. Based on these results, local decision-makers should consider that urban planning is also a fundamental tool to assure long-term local fiscal stability.
\end{abstract}

Keywords: urban sprawl, fiscal burden, local public services, geo-referenced digital cartography, quantile regression, Spain

JEL Classification: R1, R5, H7, H8 


\section{Introduction}

This paper aims to measure the impact of the increasing trend of sprawl in Spanish cities on the fiscal burden at the local level. From the theoretical perspective, the potential effect of sprawl on fiscal balances of local governments is not clear. On the one hand, the municipalities could acquire more resources from construction, local economic activities and property taxes. On the other hand, the cost of providing services and improving infrastructure could be incremental, therefore significantly reducing the efficiency in dispersed areas. Previous empirical literature has concluded that low-density areas negatively impact local service costs and fiscal stability, but, at the same time, the attraction of population and construction activities could increase the fiscal revenues.

Since the 2000-th the feasibility studies of local fiscal sustainability started taking a greater importance primarily due to the need of understanding the efficiencies of municipal budgets. The diverse approaches to the analysis and management of fiscal conditions were reflected in the Handbook of Local Government Fiscal Health, edited by Levine et al. (2013), demonstrating that while there is some agreement on fiscal health as a theoretical concept, there is still little consensus on how to measure, predict, and manage a decline in fiscal health.

Spain becomes an interesting case in discussions of urban sprawl due to its highly decentralized government, with 17 regional governments and the 8,114 municipalities that manage $35 \%$ and $13 \%$ of total public expenditures, respectively. Besides, Spain is the sixth in the degree of authority of regional governments ${ }^{1}$. Different authors have recently addressed the municipal budget issues, especially in the wake of the economic crisis where not all Spanish

\footnotetext{
${ }^{1}$ According to the Regional Authority Index on the basis of data for 2005, Spain is in the sixth position after Germany, Belgium, the United States, Canada, and Italy (Hooghe et al., 2010). This index is measured across eight dimensions: institutional depth, policy scope, fiscal autonomy, representation, law-making, executive control, fiscal control, and constitutional reform.
} 
municipalities have suffered equally the crisis (Caramés, 2005; Lopez-Laborda et al., 2006; Suárez et al, 2008; Benito et al., 2010, Martinez-Vazquez and Timofeev, 2010; Suárez and Fernández, 2012; Delgado et al., 2015). The local budgetary situation prior to the crisis, such as the size of the municipality (as the cost of providing the municipal public service is related, among others, to the greater or lesser population) and the obligation (or not) in the provision of services, had significant impact on the deterioration of municipal public accounts (Portillo, 2016). This deterioration of the local accounts is also closely related to the evolution of the urban

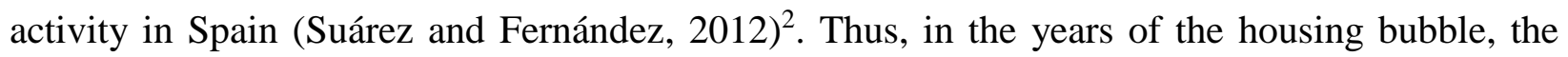
Spanish municipalities obtained a significant increase in their income, mainly as a result of the resources coming from urban planning. Later on, when the real estate bubble hit, local revenues from taxes, fees, licenses, etc. shrank.

The evolution and advancement of technologies allowed integration of quantitative information on urban sprawl within different disciplines (geography, town planning, territorial planning, the environment, economics, sociology and even public health) leading to numerous, and sometimes conflicting, definitions ${ }^{3}$ (Galster et al., 2001; Squires, 2002; Davoudi, 2003; Glaeser and Kahn, 2004; Richardson and Chnag-Hee, 2004; Sturn and Cohen, 2004; Jaeger and Schwick, 2014). For this study, while considered all indicators, we found the USI indicator measured by Rubiera et al. (2016) being the most useful and applicable. The authors used procedure for measuring sprawl proposed by Burchfield et al. (2005) and applied it to the case of Spain. Section 3.2 provides a more detailed discussion of the USI indicator as the main explanatory variable for our study of the local fiscal burden in Spain.

\footnotetext{
${ }^{2}$ For example, the Tax on buildings, facilities and works - according to data from the Ministry of Finance and Public Administration - went from providing 2,637.8 million euros to municipalities in 2006 to raise 482.2 million euros in 2014.

${ }^{3}$ For a reappraisal, see Torrens (2008), and for a focus on European cities, see Salvati and Gargiulo-Morelli (2014).
} 
The main contribution of this work is twofold. First, it contributes to the limited literature on the explanatory analysis of the local fiscal burden on taxpayers through the specified methodology of defining urban sprawl for the entire national territory of Spain. Second, it uses a very precise method of defining and measuring urban sprawl. A new digital cartography and geographical information system allows us to obtain an international comparable urban sprawl index (USI) that has not been previously used in the literature for evaluation of the fiscal consequences of urban sprawl. The USI is applied to all the urban areas of Spain. The urban structure of Spain is particularly interesting, since it contains a complete spectrum of urban areas of different sizes, economic structures, climatic and geographic conditions, while having very similar local fiscal systems and local public service obligations.

In the methodology, the ordinary least square (OLS) estimations are supplemented with the quantile regression (QR) strategy to identify how the effects of sprawl may vary across the distribution of the local fiscal burden. To observe in depth the variation of results for different types of taxation, we also separately analyse these effects through the perspective of direct and indirect taxation typical in the Spanish local fiscal system.

This paper is structured as follows. In the next section, a brief review of the literature regarding the urban sprawl phenomenon and the implications from a fiscal perspective is provided. In section 3, a description of the main variables is presented with the particular attention to the definition of urban sprawl and the calculation of the index using digital georeferenced cartography; the definition of local fiscal burden and the different taxes are included. An empirical model with the econometric strategy is presented in section 4 . Section 5 exhibits and discusses the main results. Finally, Section 6 concludes and offers policy implications. 


\section{Literature review}

Urban sprawl is one of the most studied and controversial urban phenomena. After the industrial revolution cities grew upward. While in the second part of the last century the growth pattern of some North American cities occurred through the intensive use of land, which pushed the cities further out. The North American model of a sprawled city rapidly extended, first to Latin America (Polèse and Champain, 2003) and later to Asian cities (Bunnel et al., 2002), finally becoming a global fenomenon (Bruecker, 2000). Traditionally, the old European cities were different from the newer ones of America or Asia. The cities of the old continent were strongly concentrated around a dense historical centre and its commercial and business extensions (Couch et al., 2007). However, during the last four decades, the new tendencies of urban sprawl have appeared (Arribas-Bel et al., 2011; Christiansen et al., 2011). According to the European Commission (2006), eastern and southern countries are the ones most at risk from an explosive process of urban sprawl.

The case of Spain is one of the most interesting in Europe. In some areas of the Iberian Peninsula, there is a high pressure for construction developments due to the growing tourism and the demand for second residences. The Spanish economy has been drastically affected by the construction sector, suffering one of the largest real estate bubbles of all of Europe (Romero, 2012). Spain had very rapid economic growth during the last four decades of the past century, presenting a very strong, concentrated process of urbanization. Cities such as Madrid ${ }^{4}$ and Barcelona $^{5}$ doubled their populations in less than twenty years. Other major metropolitan areas in the country experienced growth characterized by integration of different cities or towns in one

\footnotetext{
${ }^{4}$ For a specific analysis of the Madrid case, see Moliní and Salgado (2012) and Rubiera et al. (2017).

${ }^{5}$ Catalan et al. (2008) and Muñoz (2003) develop an urban sprawl analysis for the Mediterranean coast. GarcíaLópez (2012) analyze the specific case of Barcelona.
} 
unit $^{6}$. Rural areas also lost most of their populations in just two decades (Gutiérrez et al., 2017). Additionally, the explosion of the tourism sector during the last decades intensely affected many Spanish cities. According to statistical data from the Household Budget Survey of the National Statistical Institute, in 2014, approximately $35 \%$ of the population of Spain lived in houses, with $11 \%$ living in detached houses and $24.2 \%$ in semi-detached houses (INE, 2016). The remaining percentage of the population is distributed among other types of houses, such as flats. The strong changes in income per capita, social customs and land use pressures have made Spain a victim of urban sprawl (Rubiera et al., 2016; Gomez-Antonio et al., 2016).

One of the most controversial issues is the relationship between urban sprawl and local fiscal stability (McGuire and Sjoquist, 2002). The dispersion of the city increases the provisional costs of local public services, as it tends to undermine the economy of scale and to increase the costs inefficiently (Carruthers, 2002; Carruters and Ulfarsson, 2003 and 2008). Additionally, as Carruthers (2002) highlighted, low-density and spatially expansive development patterns are associated with a higher cost of public services, as the considerable investments are required to extend basic infrastructure over greater distances to reach relatively fewer number of residents. Nevertheless, as Hortas-Rico (2014) explained, dispersed cities could attract higher public resources or national funds associated with the construction activities: planning permits, construction taxes, and revenues from land value improvements from sales of public land and assets. Additionally, if the public sector owns the land, it can internalise the benefit of public investment for development and capture the gains though land sales or increased property prices (Peterson, 2009). González et al. (2013) also found evidence that the municipalities located close to large metropolitan areas in Spain were more tolerant of sprawl and attracted population. Thus,

\footnotetext{
${ }^{6}$ As an example, see the case of Asturias studied in González et al. (2013).
} 
this policy allowed inflow of higher fiscal resources for these municipalities, because, the amount of transfers from the central government to local councils is linked to the size of municipal population.

The existing empirical literature does not offer clear answers on the overall impact of sprawl on local revenues, fiscal sustainability and the level of fiscal burden. Burchell and Listokin (1978), as well as Burchell et al. (2002) standardised a simulation method to evaluate the cost-revenue impact of a particular land-use development, named the Cost of Community Service (CCS). Since the seminal work of Burchell and Listokin (1978) many researchers have used this approach to evaluate the fiscal impact of alternative scenarios, testing the effects of different urban densities and spatial patterns. Kotchen and Schulte (2009) summarised the results in a recent meta-analysis that compiled the results of $125 \mathrm{CCS}$ evaluations that were prepared for the US localities. The key finding of this literature suggested the revenues increase along with the growing population and the density, but the relevance of these variables clearly depends on local factors, such as the structure of the local economy and the scope of municipal services. For instance, density loses its relevancy in agricultural localities, and the population size appears less important when school services should be provided. The conclusions significantly vary from one place to another. Considering that this meta-analysis was made only for the US localities, the potential differences in the conclusions among different countries with different fiscal programmes and local government responsibilities may change much more intensively.

From the empirical perspective, the evidence about the impact of urban sprawl over fiscal sustainability is very limited. Heikka and Craig (1991), Kelsey (1996), Bunnell (1998), Carruthers (2002), and Carruthers and Ulfarsson (2003 and 2008) studied the impact of 
alternative residential developments on the fiscal position of local governments, finding that in general, the local governments in more disperse areas present higher indebtedness.

Through the contributions of Hortas-Rico and Solè-Olle (2010) and Hortas-Rico (2014) the fiscal perspective applied to the case of Spain has been wider studied, if compared with other European countries. In Hortas-Rico and Solè-Olle (2010), the impact of sprawl on local services costs was studied for a database of 2,500 Spanish municipalities and it was measured by population density using OLS applied to the cross-sectional data from 2003. Meanwhile, HortasRico (2014) studied the relation between sprawl and local budgets using a panel vector autoregressive model with data from 4,000 Spanish municipalities for the period from 1994 to 2005. Sprawl was also mainly measured by means of density variables. Both studies concluded that the sprawl forces an increase in local budget expenditures due to the higher cost of new infrastructure and greater provision of costs for local public services.

In contrast to the studies of the cost for providing public services focused on the revenues side of the municipal budgets, we find little literary stream analysing the Spanish local tax burden (Martinez-Vazquez and Sans-Sanz, 2007; Hortas-Rico and Solé-Olle, 2010). Most of them focus on specific geographic areas (Cárcaba, 2003; Lago Peñas, 2004; Zafra and López, 2006), and only a few studies include the entire national territory. In the latter case, we find the work of Carrasco et al. (2006), who carry out an exploratory analysis of the municipal tax burden and the works of Solé-Ollé (2006) and Bosch and Solé-Ollé (2007), where they use a sample of more than 500 municipalities throughout the national territory. In turn, Bosch et al. (2014) estimate an equation of the fiscal capacity for the two main Spanish local taxes of 86 Spanish municipalities in 2008 finding that the central costs incurred by large municipalities are offset by 
their greater fiscal capacity, but that the same is not true for municipalities that serve as political/administrative capitals.

As Hortas-Rico and Solè-Olle (2010) noted, the most fundamental point of empirical literature is the available capabilities for measuring the sprawl. Traditionally, databases only permitted the ability to approximate sprawl measurements by means of population density or density plus a combination of other demographic variables. However, the development of digital cartography with geo-referenced information allows for more precise and comparable measurements of sprawl. The use of this new approach for the quantification of sprawl allows for the ability to revise the empirical analysis, thus providing new and interesting conclusions. There is an opportunity to obtain new evidence regarding the impact of sprawl on local fiscal programmes by using sustainable geo-referenced information.

\section{Studying the Spanish case: Variables of local fiscal burden, urban sprawl index and other control variables}

\subsection{Local fiscal burden as a dependent variable: definition and measurement}

An important aspect to emphasize is the lack of homogeneity in the calculation of fiscal burden. This is a complex task due to the great heterogeneity in both population density and socio-demographic characteristics (Benito et al., 2010). In some literature fiscal burden is defined as the total amount of taxes levied on the citizens of the Spanish municipalities, where several methods have been proposed to measure the potential revenues of a municipality: i) tax

collection; ii) macroeconomic indicators, including municipal GDP or municipal income; and iii) microeconomic indicators (Zafra and López, 2006; Carrasco et al., 2006). In contrast, Cárcaba 
$(2003)^{7}$ defines fiscal burden as the volume of tax revenues relative to disposable household income, while Delgado (2006) measures tax burden as the proportion of taxes (including Social Security contributions) in GDP. Unlike these latter methods based on macroeconomic indicators, Bosch et al. (2014) use microeconomic ones through a Representative Tax System (RTS) by using the share of each type of tax in a representative budget and the tax base expressed in per capita terms.

In this study we define tax burden as the quotient between local tax revenues and the number of inhabitants, based on the first method aforementioned.

The highest level of spatial desegregation of the public administration in Spain is the municipality. Spain is made up of 8,114 municipalities (excluding the autonomous cities of Ceuta and Melilla), of which 83.76 percent are the municipalities with less than 5,000 inhabitants and they account for 12.73 percent of Spanish population (see Table 1). For comparison, combined the smallest municipalities have almost the same population size as the two largest municipalities with more than 1,000,000 inhabitants, Madrid and Barcelona municipal areas, which account for the 10.38 percent of population. But these municipalities are also, in general, very small in terms of the area and most of the large cities cover several of them ${ }^{8}$. In some specific cases, like Madrid or Barcelona, one city includes more than 50 municipalities. For this reason, we should delimit the urban metropolitan areas.

We select a sample of 657 Spanish municipalities for year 2011, considering different cohort of local fiscal burden (by quantiles), in order to approximate possible effects produced by different levels of household income, according to the second method established to measure

\footnotetext{
${ }^{7}$ This author criticizes that the use of number of inhabitants ignores the greater fiscal burden due to the income level of citizens and adds that it would be necessary to establish socio-economic variables in order to expand the characterization of the financial analysis of municipalities.

${ }^{8}$ See Figure 1, in which the municipal Spanish structure is mapped, and the real urban extensions over the municipal borders are represented.
} 
local fiscal burden (macroeconomic issues). We chose the year 2011 because it corresponds to the first year of crisis, where we can see its effects on the deterioration of the local public budget to which the municipalities did not react quickly. This financial situation was materialized in greater local expenditures in comparison to local revenues. This allows us to eliminate, in a certain way, the impact of political decisions or factors from the study. We focus only on taxes, both-direct and indirect, corresponding to chapters I and II of the liquidated income budget, for two reasons. First, they are coercive and recurrent. Second, chapter III of the income budget (corresponding to fees and other revenues) has been heavily influenced throughout the period analysed by the urban activity and its inclusion would produce a bias in the local fiscal burden ${ }^{9}$.

Some important aspects considered in the calculation of the fiscal burden. The local financing system in Spain can obtain resources from their own assets, their taxes, current transfers and capital from other public entities, wealth income, sales of real investments and even resort to debt. The municipalities also obtain resources from the CCAA, although in the latter case this process has been variable in the different regions, which has led them to an unequal and asymmetric development (Fuster, 2010). Additionally, municipalities receive grants drawn from central tax revenues without normative capacity or as a simple share of state revenues, according to various indicators of fiscal capacity and need (Delgado, 2012).

The fiscal regime of the Spanish local taxes is dual and distinguishes between large municipalities (those with more than 75,000 inhabitants and capitals of provinces or regions) and the rest (with special treatment of tourism jurisdictions). All Spanish municipalities impose three compulsory taxes: on property, economic activity, and motor vehicles. Besides, all municipalities

\footnotetext{
${ }^{9}$ It would have been desirable to subtract, from chapter III, the share of revenues corresponding to the urban activity, but there is no available data, since we only have the information aggregated by chapters. Nonetheless, at the aggregate level, we have calculated that the revenues associated with urbanistic activities in chapter III for 2011 represented 2.19\% from the total of non-financial revenues (MFPA, 2013).
} 
above a certain population tend to avail themselves of two non-compulsory taxes as well: tax on construction and building work and tax on the increase in the value of urban building land.

The local taxes can be divided into direct and indirect taxes. According to the direct taxes (in the chapter II of local revenues), along with the surcharges of state and regional direct taxes, four taxes stand out, where the municipalities have a greater autonomy when managing them:

- Tax on property: it is the main source of municipal revenues, of real character and annual periodicity. It taxes the value of the real estate, fundamentally the right of property. In particular, the measure of the tax base is the cadastral value of the properties located in the municipality.

- Tax on motor vehicles: it is periodic, of annual levy, real and patrimonial nature. It registers the ownership of vehicles suitable for driving on public roads as consideration for local public services put to the service of traffic, such as differentiation by the use of equipment and engines of different power and the negative external effects caused by pollution. Its quotas are established by the central government but municipalities can increased it by using a coefficient that ranges from 1 to 2 .

- Tax on the increase in the value of urban building land: it taxes the increase in value experienced by urban land at the moment the property or other rights are transferred. It lacks periodicity.

- Tax on economic activity: the municipal tax base (the so-called Cuotas mínimas) is the estimated contents of each business, professional and artistic activity weighted by coefficients depending on the location and turnover of the activities present in the municipality. Therefore, it comprises the mere exercise of the economic activity, but not the 
actual returns of the activity, which has caused to be a highly criticized tax. This has led to an increase in central government transfers to compensate for the loss of municipal revenues.

In relation to indirect taxes, it highlights tax on construction and building work. It accrues for the realization of any construction, installation or work for which it is required to obtain the corresponding building (or urban) planning permit, so it is not periodic. Its creation is relatively recent, in 1988, and has no previous history (background) in Spain or in other countries ${ }^{10}$.

\subsection{Urban sprawl index as the main independent variable: definition and measurement}

Burchfield et al. (2005) classify the phenomenon of urban sprawl as "whether the residential development is scattered or compact," such that "in the sprawling areas much of the land immediately surrounding the average house will not itself be developed" bringing the definition of urban sprawl down to only one dimension, the degree to which building is dispersed, thus simplifying quantification. These authors propose an Urban Sprawl Index (USI) consistent with their definition, which can be obtained via the possibilities offered by Geographic Information Systems (henceforth, GIS). These authors specifically use TM Landsat imagery at a resolution of $30 \times 30 \mathrm{~m}$, providing photo interpretation in a raster GIS scenario. This scenario indicates the delimiting of the pixels of the image as urban or rural, and for each pixel considered urban, counts the number of other urban pixels that fall within an area of $1 \mathrm{~km}^{2}$ around it, applying the following formula:

$$
\mathrm{USI}=100\left[1-\frac{\text { Urban pixel }}{18^{2} \pi}\right]
$$

\footnotetext{
${ }^{10}$ It is important to point out that of the five taxes mentioned, three are related to the urban activity: tax on property, tax on construction and building work and tax on the increase in the value of urban building land which is indicative of the financial problems that in the crisis of the construction are taking almost all of the Spanish town councils.
} 
Thus, high values of USI (up to 100) indicate high levels of dispersion or sprawl, while low values indicate concentration (Burchfield et al., 2005). This paper has had a major impact, and the approach of these authors has spread to the spheres of both geography and urban economics, with the subsequent publication of a large number of papers based on the original idea by Burchfield et al. (2005). Some of this research has broadened the scope of analysis to aspects of urban morphology or the structure of cities.

In Rubiera et al. (2016) the procedure for measuring sprawl proposed by Burchfield et al. (2005), formula [1], is applied to the specific case of Spain by exploiting the potential of the databases available for this country. Spain is covered by a wide variety of geo-referenced photos and maps with different scales and sources. One of the most precise databases comprises the orthophoto series (1:5000 scale) generated within the context of the PNOA program produced in collaboration with the IGN (National Geographic Institute of Spain) and the autonomous regions. This is the basis for producing the 1:25000 maps made by IGN in the BTN25 series. Formerly, starting in the 1970s, the IGN published vector maps based on traditional photogrammetric methods, namely, the BCN25 maps. Both series, BCN25 and BTN25, form the basis from which we obtain the built-over surface areas and economic data obtained from different official sources (CNIG, AEMET and INE) referred to the 2001 year.

This paper applies similar with Rubiera et al. (2016) estimates of USI for the studied 657 municipal areas in Spain. The USI estimates are mapped in Figure 1. The average USI for all Spanish urban areas is 68.81 . There is a strong dispersion in this index within the territory: from the metropolitan area of Seville, with the lowest value of 48.13, to Lleida, with the highest level of 81.12. Other important urban areas with a high level of sprawl include Madrid, Granada and 
Vitoria. At the other extreme are cities such as Caceres, Lugo and Santiago, with the lowest levels of sprawl. Barcelona, practically, presents the national average value.

\subsection{Other control variables: definition and measurement}

While the assessment of the local fiscal burden with consideration of the new methodology for measuring the urban sprawl is the focal point of the study; however for deeper understanding of these effects we considered the variety of other factors that could contribute to this discussion.

Thus, the factors used in the explanation of the financial performance of public administrations can capture both the expenditure and the revenue sides of municipal budgets. In relation to the revenue side, its volume is conditioned by the amount of revenue that can be collected. In this regard, the size of the fiscal revenues depends on various socioeconomic, demographic, fiscal and political variables, such as the economic level of the municipality, population, and the costs of providing services; although the sign of the influence of the economic level on the fiscal pressure has not been unequivocally demonstrated in the literature (Benito et al., 2010) ${ }^{11}$. In this regard, for instance, Delgado (2012) includes the population or total assets, and per capita income and per capita grants received as control variables to measure the local tax mix in Spain. Other studies also include variables capturing the age structure and the level of education of the population; however, these variables do not have a significant effect on the local fiscal burden (Bosch et al., 2014).

\footnotetext{
${ }^{11}$ Fiscal and political factors are not exogenous to the fiscal capacity itself and, as a result, we might face problems of endogeneity. In order to avoid this problem, these kind of factors are not considered in this study. Besides, some authors such as Benito y Bastida (2008) conclude that political ideology has no clear influence on the fiscal situation.
} 
In some ways, the local public costs could also be seen as potential revenue raisers. Apart from the obvious cases of commuting (work, studies, shopping, administrative activities and leisure) and tourism, which are easily identified as potential sources of revenue for recipient municipalities through different channels, other socioeconomic and demographic variables, including immigration, unit costs (wages) or activity substitution, could have a positive impact on a municipality's fiscal burden. Indeed, all of them could attract more economic activity and, hence, increase directly and indirectly local tax revenues (Bosch et al., 2014).

Few studies have tested whether geographic factors also affect the fiscal capacity, e.g. Bosch and Solé-Ollé (2007) included a matrix of proximity to analyse tax mimicking, and therefore analysis undertaken in this paper also represents a new contribution to the testing of this relationship.

The decision on the municipal tax collection capacity is influenced by the level of public expenditure that is intended to be made and by the transfers that are received from the central and regional public administrations and we focus on the liquidated taxes of municipality. Assuming that the municipal government has no influence over them, the taxes paid will depend on a series of factors that will determine the level of expenditure that is intended to be realized and, therefore, the level of taxation that will have to be established in order to finance it. Thus, with consideration of aforementioned objectives, we combine all supplemental to USI control variables in three main types: socioeconomic, demographic and geographic. In addition to the USI there are total of twelve supplemental control variables included in the analysis (Table 2). Except for two dummy variables, all other control variables are calculated using databases from the Spanish National Institute of Statistics and Spanish National Institute of Geography. 


\section{Empirical model and econometric strategy}

Based on the above information, the basic empirical model proposed can be written as:

$$
\text { LFISBUR }_{11}=\beta_{0}+\beta_{1} U S I_{01}+\left[\beta_{S} S+\beta_{D} D+\beta_{G} G\right]+u
$$

where,

LFISBUR 01 -local fiscal burdens for 2011 (Section 3.1)

USI $I_{01} \quad$-urban sprawl index in 2001, main independent variable (Section 3.2)

$S, D, G$-vectors with socioeconomic, demographic and geographical control variables (Section 3.3 and Table 2)

$u \quad$-random error term of the estimation

Equation [2] could be estimated by ordinary least square (OLS) regression, but we are interested in observing whether the fiscal burden changes along with the distribution. This is possible using the quantile regressions (QR) approach (Koenker and Basset, 1978), which fits quantiles of local fiscal burden to a linear function of covariates. In its simplest form, the least absolute deviation estimator fits medians to a linear function of covariates. The method of $Q R$ is more attractive, because medians and quantiles are less sensitive to outliers than means and therefore OLS regressions. Indeed, the likelihood estimator is more efficient than the OLS one. QRs allow different solutions at different quantiles to be interpreted as differences in the response of the dependent variable to changes in the regressors; thus, quantile regressions detect asymmetries in the data that cannot be detected by OLS. However, the most important feature is that quantile regressions analyses the similarity or dissimilarity of regression coefficients at different points of the dependent variable, which in this case is the local fiscal burden; it allows one to consider the possible heterogeneity across the intensity in local fiscal burden. 
The following expression presents the adaptation of equation [2] in terms of QR:

$$
L F I S B U R_{11}^{\tau}=\beta_{0}^{\tau}+\beta_{1}^{\tau} U S I_{01}+\left[\beta_{S}^{\tau} S+\beta_{D}^{\tau} D+\beta_{G}^{\tau} G\right]+u
$$

where, coefficients $\beta_{i}^{\tau}$ represent the returns to covariates at the $\tau$ th quantile of the local fiscal burden. The model is estimated by using the least-absolute value minimization technique, and bootstrap estimates of the asymptotic variances of the quantile coefficients are calculated with 20 repetitions.

The null hypothesis for equation [2] suggests that $H_{0}=\beta_{1}=\beta_{S}=\beta_{D}=\beta_{G}=0$ and equation [3] suggests that $H_{0}: \beta_{1}^{\tau}=\beta_{S}^{\tau}=\beta_{D}^{\tau}=\beta_{G}^{\tau}=0$, indicating that coefficients associated with the independent variables do not impact the dependent variables.

The $t$ - statistics associated with the coefficients we derive in the tests should exceed the value for the two-tailed t-distribution test at 5\% significance level (1.96), defining the significance of a given explanatory variable in relation to the local fiscal burden with the confidence interval at $95 \%$. Additionally, the test results also provide information on the significance of explanatory variables at $10 \%$ and $1 \%$ levels, contributing in a better assessment of the impact.

We compare OLS regression with QR estimates of the model in different quantiles $(0.25$, 0.5 and 0.75 ) and use three regression models to estimate the impact of the explanatory variables on the fiscal burden with consideration of the type of taxation: direct, indirect and aggregate of both. Thus, while the OLS regression models the relation between the independent variables (USI, and combination of socioeconomic, demographic and geographic variables) and the conditional mean of the dependent variable (local fiscal burden), the QR models the relationship of the same explanatory variables and the conditional quantiles of the response variable, giving more comprehensive picture of the effects of independent variables on the studied variable. 


\section{Main results}

Table 3 present the results obtained with the estimation of the equations [2] (by OLS) and [3] (by QR) using all local taxes in the calculation of the fiscal burden as dependent variable and with the independents variables summarized in Table 2. A heteroscedasticity and autocorrelation consistent estimator is used to provide a robust estimation of the covariance matrix of the parameters of a regression-type model. The first column of results presents the coefficient estimation by OLS regression. The following three columns report the coefficients and tstatistics for QR model estimating conditional distribution of the local fiscal burden at three quantiles ( $\tau$ th): $0.25,0.50$ and 0.75 . Basic tests $\mathrm{R}^{2}$ and F-Change as well as a Pseudo $\mathrm{R}^{2}$ for the $\mathrm{QR}$ are presented at the end of the table. In order to observe which type of taxes are more affected by urban sprawl the estimations of Table 3 are further analysed through two different sections. Table 4 provides information on the same model, but using only direct taxes. Table 5 offers a summary of the analysis relevant to the indirect taxes. In both cases we apply similar estimation procedure and use the same list of explanatory variables.

As the main objective of this paper was to measure the specific effects of the sprawl, measured by means of an urban sprawl index (USI) calculated with digital cartography and geographical information systems, over the local fiscal burden, we address this discussion first followed by the results associated with the other control variables.

\subsection{Results addressing USI}

The effects of urban sprawl on the local fiscal burden vary across the types of empirical methodologies used, conditional distribution of fiscal burden and types of taxation. Thus, after controlling for the aforementioned factors (Section 3.3), the OLS regression detected 
comparatively less strong relation of USI on local fiscal burden (only at 10\% significance). Meanwhile the QR methodology defined a very significant impact of urban sprawl on local fiscal burden as we moved up the conditional distribution of the dependent variable. As it is observable in Figure 2 (a) and Table 3, the urban sprawl index coefficient is not significantly different from zero in the quantiles 0.25 and 0.5 , but it is clearly significant and positive in the quantile 0.75 . This growing-up behaviour indicates that the sprawl is not relevant for the lower levels of local fiscal burden, but it has a clearly significant and positive effect in the higher levels of local fiscal burden. We find similar effects of USI on the local fiscal burden limited to the direct taxation in QR methodology; however, in case of OLS regression, the test did not detect significance in relation of USI and local fiscal burden (Table 4). It is very interesting to observe that the impact of USI is much stronger in case of indirect taxation. Here, USI has a significant effect on higher levels of conditional distribution ( 0.5 and 0.75 quantiles) of the local fiscal burden in indirect taxes in QR and the effect is also statistically significant in OLS (Table 5). This is directly related to the characteristics of local indirect taxation in Spain, which is mainly focused on taxation of construction related activities and urban sprawl has a direct impact on that.

From the technical standpoint the discrepancy in outcomes for OLS and QR methodologies justify the use of $\mathrm{QR}$ as a more accurate econometric instrument for defining the effects of urban sprawl on the local fiscal burden in Spain. Additionally, the discussed outcomes confirmed the useful strategy for analysing tax burden through the types of taxation. The OLS methodology detected less strong statistical significance (10\% significance level) from the USI to all taxes, which was mainly attributable to the share of strong relation of the effect of USI on indirect taxes. On the contrary, based on the OLS the direct taxation was insignificantly impacted by USI. Nevertheless, the QR methodology, while confirming strong fiscal pressure of USI 
through indirect taxation, also confirmed strong contribution of USI on the higher levels of conditional distribution ( 0.75 quantile) of fiscal pressure in all taxes and direct taxes (Figure 2 (a), (b) and (c)).

From the economics perspective, it is interesting to observe that while the construction and building businesses, as one of the primary beneficiaries of urban sprawl, contribute a significant share of taxes in the form of indirect taxation; however, the USI becomes a significant factor for the taxpayers in the higher levels of direct tax distribution, causing them to reallocate considerable share of their taxes in support of increasing costs for providing municipal services and growing infrastructure.

These results are coherent with the ones obtained in previous similar analysis for the Spanish case, like the ones of Hortas-Rico and Solè-Olle (2010) and Hortas-Rico (2014). They also confirm the main international evidence about the negative effect of sprawl in the local public services costs or local fiscal sustainability (see, for instance, Heikka and Craig (1991), Kelsey (1996), Bunnell (1998), Carruthers (2002), Carruthers and Ulfarsson (2003 and 2008)).

\subsection{Results addressing other control variables}

All the control variables considered are significant in the OLS estimation and, in general, these are expected outcomes if considered the previous empirical literature on the causes of local fiscal burden (Section 3.3 and the recent studies for the Spanish case of Bosch and Solé-Ollé (2007) and Bosch et al. (2014)). The QR results reveal interesting additional information. Thus, we obtain that overall the local fiscal system in Spain is progressive, where taxpayers in higher conditional distribution of fiscal burden contribute more significantly in supporting fiscal health of municipalities and the main fiscal sources are drawn from the direct taxation. The variables 
that have a significant impact on the overall conditional distribution of the fiscal burden with a greater magnitude as it moves up, explaining higher local fiscal pressure, are the in the local economy, location in terms of longitude and whether it's a unemployment ratio, the percentage of foreign population, the location quotient of primary sector coastal municipality. When the estimations are focused on indirect taxes most of the variables lose their significance with only some particular cases. These observations are true for the majority of socio-economic, demographic and geographic variables considered, with some exceptions which we will discuss below.

The results for the socio-economic condition index and the specialization index of local economy suggest that overall the fiscal pressure has a progressive nature and it is related to direct taxation. However, our analysis suggests some distortions across conditional distribution of the fiscal burden. Thus, while the taxpayers in 0.25 and 0.75 quantiles are significantly involved in supporting of the programs targeted to socio-economic conduction, the ones in the median are not contributing at the same level. The similar distortive result is derived for the case of the specialization index of local economy, where the main fiscal pressure for supporting these activities is on the taxpayers in the 0.75 quantile of the conditional distribution. These results are coherent across all taxes and direct taxes, suggesting uneven distribution of fiscal pressure across taxpayers' groups.

The cities that are capitals of the Spanish Autonomous Communities or Provinces, which have to provide a larger range of public services also contribute in higher tax burden. Here, we observe that the fiscal programs are supported by both direct and indirect taxation. In case of the aggregate fiscal pressure the analysis suggest that the tax burden across its conditional distribution is comparatively fair distributed. However, the studies for tax burden by 
type of taxation suggest that overall the indirect taxes have stronger contribution than the direct taxes. In case of direct taxes the ones in the lower and median ( 0.25 and 0.5 quantiles $)$ points of conditional distribution of fiscal burden are under stronger pressure, and it becomes insignificant in the higher levels (0.75). While the direct taxation assesses the regressive nature of tax burden, the indirect taxation analysis suggests that the majority of the programs in municipal and provincial capitals are supported through influx of resources from building and construction activities and infrastructure development.

In case of occupation ratio, we asses higher fiscal pressure in the lower (0.25) quantile and the pressure is insignificant in higher quantiles. This information holds for both, all taxes and direct tax, cases. This analysis suggests more regressive character of local direct taxation. Additionally, when we combine information derived from the analysis of indirect fiscal pressure, here the OLS detects less strong (10\% significance) fiscal pressure related to the increase in occupation ratio, while the $\mathrm{QR}$ does not detect any significance along the conditional distribution. Economically, the results related to the occupation indirectly suggest the distortion of the local fiscal system. Here we can assume, while the value of the taxable base for direct taxes, such as property, land and number of motor vehicles, is lower in the areas with lower rate of occupation; however people are subjected to a significant fiscal pressure, which in turn, may cause the most successful employees to move to the regions with higher occupation and insignificant fiscal pressure. In this instance we would anticipate municipal policies contributing in more balanced fiscal pressure across all groups of employed population.

On the contrary, in general the explanatory variables for population density, the distance to metropolitan area of more than 500,000 inhabitants and the location of primary sector area in the local economy perform almost identically when all taxes and direct taxes are considered. 
In both cases the tests assess a very significant negative relation of these explanatory variables in relation to the local fiscal burden, suggesting less fiscal pressure when people move further out of the large metropolitan areas or primary sectors of economic activity and similarly in the areas with higher density. Interestingly, the change in density does not cause fiscal pressure in indirect taxes using OLS method; on the contrary, the QR methodology assesses a negative significant impact of density on the lower level (0.25) of conditional distribution of the indirect tax burden.

In case of indirect fiscal pressure for metropolitan areas of more than 500,000 inhabitants, the OLS methodology suggests comparatively weaker (10\% significance level) pressure due to the change in the distance; however, the $\mathrm{QR}$ does not find evidence of strong causality. In case of location of primary sector of local economy both the OLS and QR in its median (10\% significance) and higher quantile assess a negative and significant effect on fiscal burden. In the context of these three explanatory variables, it can be assumed that the lowest density areas and further distance from the primary sector of local economy promoted construction activities with beneficial regulations addressing indirect taxation. Additionally, it can be assumed that non-tax, but intergovernmental transfers were the main sources of local revenues that covered expenditures associated with the changes in density of population and in distances from large metropolitan areas and primary sectors of local economy, such as costs of infrastructure, construction and building developments, etc. These outcomes are consistent with the available literature (Hortas-Rico M., 2014). 


\section{Conclusions and policy implications}

The primary objective of this paper was a thorough study of the effects of urban sprawl on local fiscal burden, while considering a number of socio-economic, demographic and geographic control variables, applied to the case of Spain. Previous literature accumulated evidence that indicates that higher levels of sprawl undermine the economies of scale in the provision of public services and increase the needs for investments in infrastructure in larger areas with lower density. But, at the same time, the sprawled areas are more attractive for builder and construction development companies and influx of population, and both are relevant factors to increase the fiscal revenues.

Our results for the case of Spain show that the relationship between urban sprawl and local fiscal burden vary across types of taxation and conditional distribution of fiscal pressure. Overall, there is an evidence indicating that the sprawled cities increase the fiscal pressure. This outcome has stronger holds with considerations that the fiscal revenues could be incremented through the local taxes on construction activities and the higher transfers for the growing population supported by the Spanish fiscal system. We also observed that the urban sprawl appears more relevant to the higher levels of the conditional distribution of local fiscal burden for both direct and indirect taxes. This means that the level of sprawl is especially important for studying the localities with higher fiscal pressures. Finally, we also observed the fiscal burden associated with the sprawled areas is more evenly distributed through indirect taxation, which is mainly associated with the influx of local revenues from construction and development activities.

These conclusions suggest several policy implications. First, according to our results relaxing the urban planning or the land policies in order to increase local fiscal revenues can destabilize the fiscal sustainability on the long run. Second, compact cities are not only more 
sustainable in terms of energy consumption or social stability, as several research studies have highlighted, but they are also more sustainable in terms of fiscal pressure. Finally, urban planning, in addition to being a land use and environmental tool, should also be considered as an effective instrument for maintaining fiscal sustainability. 


\section{References}

Arribas-Bel, D., Nijkemp, P. and Scholten, H., 2011. Multidimensional urban sprawl in Europe: a self-organizing map approach. Computers, Enviroment and Urban Systems, 35 (4), 263-275.

Benito Pérez, B. Bastida Albaladejo, F. and Muñoz, M.J. (2010): "Factores explicativos de la presión fiscal municipal". Revista de Contabilidad, vol. 13 (2), 239-283.

Benito Pérez, B. y Bastida Albaladejo, F. (2008). Política y gestión financiera municipal. Revista de contabilidad, 11 (2), 43-66.

Bosch, N. and Solé-Ollé, A. 2007. Yardstick competition and the political costs of raising taxes: an empirical analysis of Spanish municipalities. International Tax and Public Finance, 14 (1), 71-92.

Bosch, N.; Espasa, M. and Montolio, D. 2014. Should Large Spanish Municipalities Be Financially Compensated? Costs and Benefits of Being a Capital/Central Municipality. Hacienda Pública Española/Review of Public Economics, 211(4), 67-91.

Brueckner, J.K., 2000. Urban growth models with durable housing: an overview. In Huriot, J.M. and Thisse, J.F., (eds.) Economics of Cities: Theoretical Perspectives. Cambridge: Cambridge University Press, 263-289.

Buchell, R. and Listokin, D., 1978. The fiscal impact handbook: projecting the local cost and revenues related to growth. Center for Urban Policy Research, New Brunswick.

Bunnel, T., Drummond, L.B.W. and Ho, K.C., 2002. Critical reflections on cities in Southern Asia. Singapore: Brill Academic Press.

Bunnell, G., 1998. Analyzing the fiscal impact of development: lessons for building successful communities. Community Development, 29: 38-57.

Burchfield, M., Overman, H.G., Puga, D. and Turner, M.A., 2005. Causes of Sprawl: a portrait from space. The Quarterly Journal of Economics, 121(2): 587-633.

Caramés Viéitez, L. 2005. Consideraciones en torno al tamaño de los municipios, Papeles y Memorias de la Real Academia de Ciencias Morales y Políticas, 13, 40-45.

Cárcaba García, A. 2003. Análisis financiero de las entidades locales mediante el uso de indicadores. Revista Española de Financiación y Contabilidad, 118, 661-692.

Carrasco, D.; Navarro, A. y Buendía, D. 2006. Análisis de la presión fiscal municipal y sus factores influyentes. Málaga: Universidad de Málaga. 
Carruthers, J.I., 2002. The impacts of state growth management programmers: a comparative analysis, Urban Studies, 39 (11): 1956-1982.

Carruthers, J.I. and Ulfarsson, G.F., 2003. Urban sprawl and the cost of public services, Environmental and planning B, 30: 503-522.

Carruthers, J.I. and Ulfarsson, G.F., 2008. Does smart growth matter to public finance? Evidence from the United States, Urban Studies, 45 (9): 1791-1823.

Catalan, B., Saurí, D. and Serra, P., 2008. Urban sprawl in the Mediterranean?: Patterns of growth and change in Barcelona Metropolitan Region 1993-2000. Landscape and Urban Planning, 85(3-4): 174-184.

Christiansen, P. and Loftsgarden, T., 2011. Drivers behind urban sprawl in Europe. TOI Report 1136/2011. Institute of Transport Economics, Norwegian Centre for Transport Research.

Couch, C., Ldontidou, L. and Petschel-Held, G., 2007. Urban Sprawl in Europe. Landscapes, Land-Use Change \& Policy. Oxford: Blackwell Publishing.

Davoudi, S., 2003. European briefing: polycentricity in European spatial planning: from an analytical tool to a normative agenda. European Planning Studies, 11(8): pp. 979-999.

Delgado, F.J. 2006. Are the tax mix and the fiscal pressure converging in the European Union?. Papeles de trabajo del Instituto de Estudios Fiscales, Serie Economía, nº 11.

Delgado, F. J. 2012. Determinants of Local Tax Mix: Evidence from Spain. Lex LocalisJournal of Local Self-Government, 10(4), 311-21.

Downs, A., 1999. Some realities about sprawl and urban decline, Housing Policy Debate, 10 (4): 955-974.

Dwyer, J.F. and Childs, G.M., 2004. Movement of people across landscape: a blurring of distinctions between areas, interest and issues affecting natural resource management. Landscape and Urban Planning, 69(2/3): 153-164.

European Commission, 2006. Environmental aspects of urban spread in Europe. Joint Research Centre, European Commission.

Fishman, R., 1978. Urban utopias: the rise and fall of suburbia. New York: Basic Books.

Fuster Asencio, M.C. 2010. Situación actual de las corporaciones locales: competencias y recursos. Crónica Tributaria, 136, 103-125.

Galster, G., Ratcliffe, M.R., Wolman, H., Coleman, S. and Freihage, J., 2001. Wrestling sprawl to the ground: Defining and measuring an elusive concept. Housing Policy Debate, 12 (4): 681-717. 
García-Lopez, M.A., 2012. Urban spatial structure, suburbanization and transportation in Barcelona. Journal of Urban Economics, 72: 176-190.

Gilbert, A., 1996. The Mega-city in Latin America. Tokyo: United Nations University Press

Glaeser, E. and Kahn, M., 2004. Sprawl and urban growth. In Henderson, V. and Thisse, J.F. (eds.) Handbook of Regional and Urban Economics, vol. 4. Amsterdam: North-Holland, 2481-2527.

Gómez-Antonio, M., Hortas-Rico, M. and Li, L., 2016. The causes of urban sprawl in Spanish urban areas: a spatial approach. Spatial Economic Analysis, 11 (2): 219-247.

González, V.M., Rubiera, F. and Rivero, J.L., 2013. Dispersión urbana en áreas metropolitanas policéntricas: análisis del caso asturiano mediante el uso de sistemas de información geográfica. ACE: Architecture, City and Environment = Arquitectura, Ciudad y Entorno, 8 (24): 38-63.

Gutiérrez, D., Rubiera, F. and Viñuela, A., 2017. Heterogeneity in the determinants of the population growth at the local level. Analysis of the Spanish case with GWR approach. International Regional Science Review, 40 (3): 211-240.

Heikkila, E. and Craig, S. 1991. Nested fiscal impact measures using the new theory of local public goods. Journal of Regional Science, 31: 65-81.

Hooghe,L., G. Marks, and A.H. Schakel The Rise of Regional Authority: A Comparative Study of 42 Democracies (1950-2006). London: Routledge, 2010.

Hortas-Rico, M. 2014. Urban sprawl and municipal budgets in Spain: a dynamic panel data approach. Papers in Regional Science, 93 (4), 843-864.

Hortas-Rico, M. and Solé-Ollé, A. (2010) Does urban sprawl increase the cost of providing local public services? Evidence from Spanish municipalities, Urban Studies, 47 (7): 15131540 .

INE (Instituto Nacional de Estadística) (2016) Household budget survey, 2014. Madrid: Instituto Nacional de Estadística.

Jacobs, J. 1962. The death and life of the American cities. Middlesex. England: Penguin.

Jaeger, J.A.G. and Schwick, C., 2014. Improving the measurement of urban sprawl: Weighted Urban Proliferation (WUP) and its application to Switzerland. Ecological Indicators, 38: 294-308.

Lago Peñas, S. (2004). Local governments' asymmetric reactions to grants: looking for the reasons. Papeles de trabajo del Instituto de Estudios Fiscales, Serie Economía, no 22. 
Levine, H.C., Justice J.B., and Scorsone E.A., eds. 2013. Handbook of Local Government Fiscal Health. Burlington, MA: Jones and Bartlett Learning.

Lopez-Laborda J., Martinez-Vazquez J., and Monasterio C., (2006). The practice of fiscal federalism in Spain. International Studies Program, Georgia State University, WP 06-23

Martinez-Vazquez J. and Sans-Sanz F. (eds.), 2007. Fiscal Reform in Spain. Cheltenham, UK: Edward Elgar, 2007

Martinez-Vazquez J. and Timofeev A. (2010). Choosing between Centralized and Decentralized Models of Tax Administration. International Journal of Public Administration, 33: 12-13, 601-619

McGuire, T.J. and Sjoquist, D.L., 2002. Urban sprawl and the finances of state and local governments. In D.L. Sjoquist (Ed.) State and local finances under pressure, 299-326. Cheltenham: Edward Elgar.

Ministerio de Fomento, 2011. Las Áreas Urbanas. Documento del Ministerio de Fomento.

Moliní, F. and Salgado, M., 2012. Sprawl in Spain and Madrid: a low starting point growing fast. European Planning Studies, 20(6): 1075-1092.

Muñoz, F. 2003. Lock living: urban sprawl in Mediterranean cities, Cities, 20(6): 381-385.

Kelsey, T.W., 1996. The fiscal impacts of alternative land uses: what do cost community services studies really tell us? Journal of Community Development, 27: 78-89.

Koenker, R. and Basset, J.G., 1978. Regression quantiles. Econometrica , 46 (1): 33-50.

Kotchen, M. and Schutle, S., 2009. A meta-analysis of cost community service studies. International Regional Science Review, 32: 376-399.

Peiser, R. 2001. Desconposing urban sprawl. Town Planning Review, 72(3): 275-298.

Peterson, G.E., 2009. Unlocking land values to finance urban structure. Trends and Polycy Options Series Public-Private Infrastructure Advisory Facility, Washington: World Bank.

Polèse, M. and Champain, C., 2003. La evolución de los centros urbanos: La experiencia de América del Norte. Washington: World Bank.

Portillo Navarro, M.J. (2016). Economic crisis and municipalities: Analysis through indicators budget according to size. Revista de Estudios Regionales, 107, 207-237.

Romero, J. 2012. Construcción residencial y gobierno del territorio de España. De la burbuja especulativa a la recesión, causas y consecuencias. Cuadernos Geográficos, 47: 17-46. 
Rubiera, F., González. V. and Rivero, J.L., 2016. Urban sprawl in Spain: differences among cities and causes. European Planning Studies, 24 (1): 204-226.

Rubiera, F., Marroquin, V.M. and Rivero, J.L., 2017. Urban sprawl in Madrid? An analysis of the urban growth of Madrid during the last quarter of the XX century. Letters in Spatial and Resources and Sciences, 10 (2): 205-214.

Richardson, H.W. and Chang-Hee, C.B. 2004. Urban sprawl in Western Europe and the United States. Ashgate, London.

Salvati, L. and Gargiulo-Morelli, V. 2014. Unveiling urban sprawl in the Mediterranean Region: towards a latent urban transformation?, International Journal of Urban and Regional Research, 38(6): 1935-1953.

Solé-Ollé, A. 2006. The effects of party competition on budges outcomes: empirical evidence from local government in Spain. Public Choice, 126 (1), 145-176.

Squires, G.D., 2002. Sprawl: causes and consequences and policy responses. Washington: The Urban Institute Press.

Suárez Pandiello, J. y Fernández Llera, R. 2012. Impactos de la crisis sobre la Hacienda local española:datos y retos básicos. En: PORTILLO NAVARRO, M. J. y MERINO ESTRADA, V. Crisis económica y entidades locales, Valladolid, Lex Nova, 59-92.

Suárez Pandiello, J. (coord.); Bosch Roca, N.; Pedraja Chaparro, F.; Rubio Guerrero, J.J. and Utrilla De La Hoz, A. 2008. La financiación local en España: radiografía del presente y propuestas de futuro. Madrid, FEMP.

Sturm, P.C. and Cohen, D.A. 2004. Suburban sprawl and physical and metal health. Public health, 118(7): 488-496

Torrens, P., 2008. A toolkit for measuring sprawl. Applied Spatial Analysis and Policy, 1 (1): 536.

Zafra, J.L. y López, A.M. (2006). La valoración de la condición financiera de los ayuntamientos andaluces. Auditoría Pública, 39, 41-52. 


\section{APPENDICES}

Table 1. Municipalities and population in Spain, year $2011^{12}$

\begin{tabular}{|c|c|c|c|c|c|}
\hline \multicolumn{6}{|c|}{ Spain $^{(a)}$} \\
\hline $\begin{array}{c}\text { Number } \\
\text { Inhabitants } \\
\text { (in thousands) }\end{array}$ & $\begin{array}{c}\text { Number } \\
\text { Municipalitie } \\
\text { s }\end{array}$ & $\begin{array}{c}\% \\
\text { total in } \\
\text { numbe } \\
r \text { of } \\
\text { munici } \\
\text { palities }\end{array}$ & $\begin{array}{c}\text { Population } \\
(01 / 01 / 2011)\end{array}$ & $\begin{array}{l}\% \text { in } \\
\text { total } \\
\text { popul } \\
\text { ation }\end{array}$ & $\begin{array}{c}\text { Population/ } \\
\text { Municipalities }\end{array}$ \\
\hline$>1,000$ & 2 & 0.02 & $4,880,486$ & 10.38 & $2,440,243$ \\
\hline $500-1,000$ & 4 & 0.05 & $2,743,809$ & 5.83 & $685,952.25$ \\
\hline $100-500$ & 57 & 0.70 & $11,186,947$ & 23.79 & $196,262.23$ \\
\hline $50-100$ & 80 & 0.99 & $5,696,848$ & 12.11 & $71,210.60$ \\
\hline $20-50$ & 253 & 3.12 & $7,499,173$ & 15.95 & 29,641 \\
\hline $5-20$ & 922 & 11.36 & $9,034,186$ & 19.21 & $9,798.47$ \\
\hline$<5$ & 6796 & 83.76 & $5,988,192$ & 12.73 & 881.13 \\
\hline Total & 8114 & 100 & $47,029,641$ & 100 & $5,796.11$ \\
\hline \multicolumn{6}{|c|}{ Sample: Extended Urban Zones (EUZ) } \\
\hline $\begin{array}{c}\text { Number } \\
\text { Inhabitants } \\
\text { (in thousands) }\end{array}$ & $\begin{array}{c}\text { Number } \\
\text { Municipalitie } \\
\text { s }\end{array}$ & $\%$ & $\begin{array}{l}\text { Population } \\
(01 / 01 / 2011\end{array}$ & $\%$ & $\begin{array}{c}\text { Population/ } \\
\text { Municipalities }\end{array}$ \\
\hline$>1,000$ & 2 & 0.30 & $4,880,486$ & 16.62 & $2,440,243$ \\
\hline $500-1,000$ & 4 & 0.61 & $2,743,809$ & 9.34 & $685,952.25$ \\
\hline $100-500$ & 52 & 7.91 & $9,921,453$ & 33.78 & $190,797.17$ \\
\hline $50-100$ & 74 & 11.26 & $5,327,459$ & 18.14 & $71,992.69$ \\
\hline $20-50$ & 111 & 17.05 & $3,404,624$ & 11.59 & $30,672.29$ \\
\hline $5-20$ & 240 & 36.53 & $2,619,183$ & 8.92 & $10,913.26$ \\
\hline$<5$ & 174 & 26.33 & 472,581 & 1.61 & $2,715.98$ \\
\hline Total & 657 & 100 & $29,369,595$ & 100 & $44,702.58$ \\
\hline
\end{tabular}

Note: ${ }^{(a)}$ with the exception of Ceuta y Melilla.

Source: Own elaboration from data of MFPA (2013).

12 This table shows the percentage of municipalities included in the sample from the total existing for each cohort by population. Nevertheless, the classifications for the Extended Areas related to USI are different, since they included the sprawled areas around the most populated municipalities. Thus, for instance, under this criteria Madrid or Barcelona includes more than 50 municipalities. 
Figure 1. Map of urban sprawl index for the major Spanish urban and metropolitan areas, $2001^{13}$

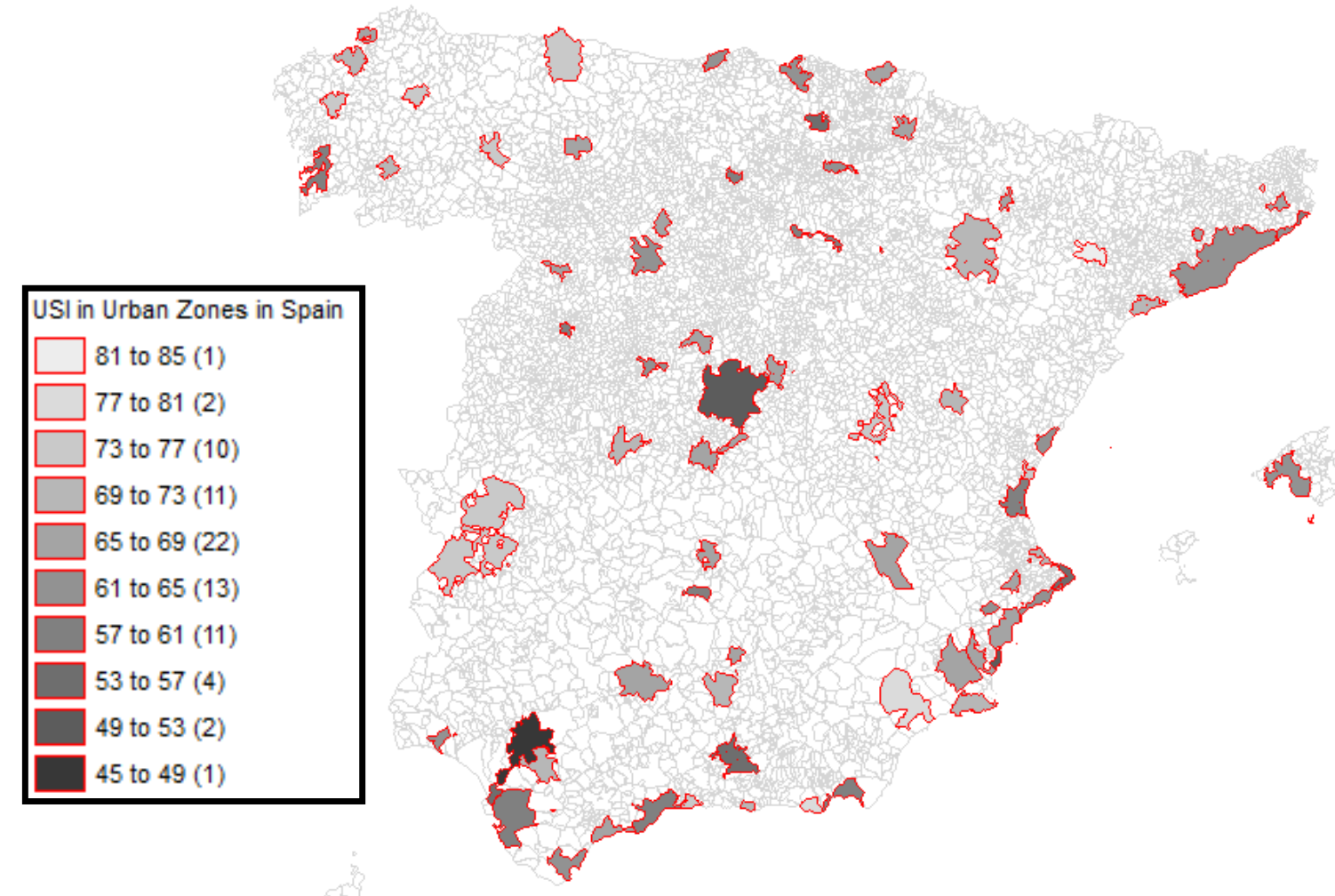

13 For detailed information on the USI estimates for the major Spanish urban and metropolitan areas, please see Rubiera et al. (2016). 
Table 2. Variables: description and descriptive statistics

\begin{tabular}{|c|c|c|c|c|c|c|}
\hline Variable & Description & Source & Year & Median & Min & Max \\
\hline \multicolumn{7}{|c|}{ Dependent variable: LFISBUR } \\
\hline$L_{F I S B U R_{11}}$ & Local fiscal burden & $\begin{array}{l}\text { IEF (Spanish } \\
\text { National Institute of } \\
\text { Fiscal Studies) }\end{array}$ & 2011 & 389.68 & 0 & 957.12 \\
\hline \multicolumn{7}{|c|}{ Main independent variable: USIO1 } \\
\hline$U S I_{01}$ & $\begin{array}{l}\text { Urban sprawl index calculated according } \\
\text { with equation [1] }\end{array}$ & $\begin{array}{l}\text { CNIG (Spanish } \\
\text { National Institute of } \\
\text { Geography) }\end{array}$ & 2001 & 66.57 & 23.63 & 96.17 \\
\hline \multicolumn{7}{|c|}{ Control variables } \\
\hline \multicolumn{7}{|c|}{ Socioeconomic variables $(S)$} \\
\hline SOCECIOI & Socio-economic condition index & $\begin{array}{c}\text { INE (Spanish } \\
\text { National Institute of } \\
\text { Statistics) } \\
\end{array}$ & 2001 & 1.03 & 0.67 & 1.36 \\
\hline$S P E C I_{01}$ & $\begin{array}{l}\text { Specialization index of the local economy } \\
\text { (a) }\end{array}$ & INE & 2001 & 3.36 & 1.45 & 7.95 \\
\hline$L_{Q P R I M}{ }_{0 I}$ & $\begin{array}{l}\text { Location quotient of primary sector in the } \\
\text { local economy }\end{array}$ & INE & 2001 & 89.34 & 2.94 & 631.27 \\
\hline$L Q S E R V_{01}$ & $\begin{array}{l}\text { Location quotient of service sector } \\
\text { activities in the local economy }\end{array}$ & INE & 2001 & 4.04 & 0.67 & 13.48 \\
\hline CAPITAL & $\begin{array}{l}\text { Dummy variable that takes value } 1 \text { if the } \\
\text { municipality is the capital of the } \\
\text { autonomous community or province and } 0 \\
\text { otherwise }\end{array}$ & - & - & - & 0 & 1 \\
\hline UNEM\%o1 & $\begin{array}{l}\text { Percentage of occupied population over } \\
\text { the sum of employed and unemployed } \\
\text { population }\end{array}$ & INE & 2001 & 11.47 & 1.43 & 33.11 \\
\hline OCUP\%o1 & $\begin{array}{l}\text { Percentage of unemployed population over } \\
\text { total population }\end{array}$ & INE & 2001 & 0.51 & 0.25 & 0.70 \\
\hline \multicolumn{7}{|c|}{ Demographic variables $(D)$} \\
\hline DENSITY $_{01}$ & Habitants per $\mathrm{km}^{2}$ & INE & 2001 & 1.89 & 0.04 & 30.13 \\
\hline FOREIN\%OI & $\begin{array}{l}\text { Percentage of foreign population over total } \\
\text { population }\end{array}$ & INE & 2001 & 0.04 & 0.00 & 0.49 \\
\hline \multicolumn{7}{|c|}{ Geographical variables $(G)$} \\
\hline EASTING & Location in terms of longitude & CNIG & - & -1.89 & -8.85 & 3.13 \\
\hline COAST & $\begin{array}{l}\text { Dummy variable that takes value } 1 \text { for the } \\
\text { coastal municipalities of and } 0 \text { otherwise }\end{array}$ & - & - & - & 0 & 1 \\
\hline DISTMA0I & $\begin{array}{l}\text { Distance (in } \mathrm{Km} \text { ) to a metropolitan area of } \\
\text { more than } 500,000 \text { inhabitants }\end{array}$ & CNIG & 2001 & 1.19 & 0 & 5.60 \\
\hline
\end{tabular}

Note: ${ }^{\text {(a) }}$ The specialization index is calculated for each local area $r$ applying this formula: SPECI $=$

$\operatorname{Ln}\left[\frac{1}{\sum_{i=1}^{n} E m p_{i}} \sqrt{\sum_{i=1}^{n}\left(E m p_{i}\left(L Q_{i}-100\right)\right)^{2}}\right]$, where $L Q_{i}$ is the location quotient of sector $i$ for local area $r$; and $E_{i}$ is the employment in sector $i$ for area $r$. Accordingly, values tend to - $\infty$ when the degree of specialization in the local area is identical to that of the whole national economy; the value tends to $+\infty$ as the specialization profile of the local area diverges from the overall Spanish specialization (i.e., when the LLM is more specialized in one or more of the $\mathrm{n}$ sectors analyzed). 
Table 3. OLS and QR estimates calculating the local fiscal burden with all taxes ${ }^{\text {(a) }}$

\begin{tabular}{|c|c|c|c|c|}
\hline & $\mathrm{OC}_{\mathrm{C}}$ & & QR & \\
\hline & ULS & 0.25 & 0.50 & 0.75 \\
\hline Constant & -280.82 & -77.20 & -116.72 & -418.70 \\
\hline Consiant & $(-2.46)^{* *}$ & $(-0.76)$ & $(-0.86)$ & $(-2.96) * * *$ \\
\hline$I C I$ & 0.99 & -0.28 & 0.98 & 1.67 \\
\hline UDI01 & $(1.94)^{*}$ & $(-0.63)$ & (1.61) & $(2.64) * * *$ \\
\hline СOCECI & 276.40 & 214.13 & 186.86 & 420.88 \\
\hline SOCEC101 & $(2.81)^{* * *}$ & $(2.43)^{* *}$ & (1.60) & $(3.44)^{* * *}$ \\
\hline CDTCI & 21.37 & 6.17 & 5.46 & 30.22 \\
\hline$\triangle P E C I_{01}$ & $(3.33) * * *$ & (1.07) & $(0.71)$ & $(3.79) * * *$ \\
\hline$I A P R I M$ & -0.25 & -0.18 & -0.17 & -0.26 \\
\hline LQT МIVI0I & $(-4.15)^{* * *}$ & $(-3.27) * * *$ & $(-2.38) * *$ & $(-3.39) * * *$ \\
\hline$I O S E D V$ & 18.75 & 10.08 & 22.54 & 24.37 \\
\hline LQSEKV 01 & $(4.13) * * *$ & $(2.48)^{* *}$ & $(4.18)^{* * *}$ & $(4.33)^{* *}$ \\
\hline C ADITAT & 52.77 & 64.68 & 55.22 & 52.40 \\
\hline CAPIIAL & $(2.71)^{* * *}$ & $(3.71)^{* * *}$ & $(2.39)^{* *}$ & $(2.17)^{* *}$ \\
\hline ACUDO & 296.58 & 229.99 & 248.11 & 175.48 \\
\hline OCOT & $(2.45)^{* *}$ & $(2.13)^{* *}$ & $(1.73)^{*}$ & (1.17) \\
\hline IUNEMO & 6.96 & 5.82 & 5.67 & 8.43 \\
\hline UNEIV\% $\% 01$ & $(3.85)^{* * *}$ & $(3.60) * * *$ & $(2.64) * * *$ & $(3.73) * * *$ \\
\hline DENSITV & -16.72 & -17.97 & -20.78 & -21.48 \\
\hline DENSII $Y_{01}$ & $(-5.78) * * *$ & $(-6.93) * * *$ & $(-6.04)^{* * *}$ & $(-5.98) * * *$ \\
\hline EOPEINO & 401.36 & 195.59 & 289.02 & 609.74 \\
\hline FUREIN\%OOI & $(3.68) * * *$ & $(2.00)^{* *}$ & $(2.23)^{* *}$ & $(4.51)^{* * *}$ \\
\hline DISTMM & -17.38 & -17.38 & -13.84 & -18.57 \\
\hline DID МИAОI & $(-3.13)^{* * *}$ & $(-3.13) * * *$ & $(-2.10)^{* *}$ & $(-2.70)^{* * *}$ \\
\hline$E \triangle$ CTINC & 9.48 & 9.50 & 11.78 & 10.16 \\
\hline EADIIIVG & $(3.52)^{* * *}$ & $(3.94) * * *$ & $(3.68) * * *$ & $(3.04) * * *$ \\
\hline COA $\mathrm{CT}$ & 72.77 & 72.77 & 54.13 & 84.34 \\
\hline CUASI & $(5.52)^{* * *}$ & $(5.52) * * *$ & $(4.59) * * *$ & $(5.16) * * *$ \\
\hline Ajusted $\mathrm{R}^{2}$ & 0.41 & & & \\
\hline Pseudo $\mathrm{R}^{2}$ & & 0.26 & 0.27 & 0.29 \\
\hline F-Change & 35.98 & & & \\
\hline
\end{tabular}

Note: $*, * *$ and $* * *$ represent estimates significantly different from zero at $10 \%, 5 \%$ and $1 \%$, respectively.

(a) To overcome any possible autocorrelation and heteroskedasticity in the error terms in the models, an Heteroskedasticity and Autocorrelation Consistent estimator is used to provide a robust estimation of the covariance matrix of the parameters of a regression-type model. 
Table 4. OLS and QR estimates calculating the local fiscal burden with direct taxes

\begin{tabular}{|c|c|c|c|c|}
\hline & OI & & QR & \\
\hline & UES & 0.25 & 0.50 & 0.75 \\
\hline Constant & $\begin{array}{r}-249.67 \\
(-2.26)^{* *}\end{array}$ & $\begin{array}{r}-160.89 \\
(-1.46)\end{array}$ & $\begin{array}{l}-73.20 \\
(-0.59)\end{array}$ & $\begin{array}{r}-433.87 \\
(-2.83) * *\end{array}$ \\
\hline$U S I_{0 I}$ & $\begin{array}{r}0.67 \\
(1.36)\end{array}$ & $\begin{array}{r}-0.32 \\
(-0.65)\end{array}$ & $\begin{array}{r}0.67 \\
(1.20)\end{array}$ & $\begin{array}{r}1.49 \\
(2.17)^{* * *}\end{array}$ \\
\hline$S O C E C I_{01}$ & $\begin{array}{r}270.37 \\
(2.83) * * *\end{array}$ & $\begin{array}{r}248.51 \\
(2.62)^{* * * *}\end{array}$ & $\begin{array}{l}194.92 \\
(1.82)^{*}\end{array}$ & $\begin{array}{r}443.26 \\
(3.34)^{* * * *}\end{array}$ \\
\hline$S P E C I_{01}$ & $\begin{array}{r}22.53 \\
(3.61)^{* * * *}\end{array}$ & $\begin{array}{r}7.85 \\
(1.27)\end{array}$ & $\begin{array}{l}10.46 \\
(1.50)\end{array}$ & $\begin{array}{r}32.63 \\
(3.77) * * *\end{array}$ \\
\hline$L_{Q P R I M_{0 I}}$ & $\begin{array}{r}-0.23 \\
(-3.85) * * * *\end{array}$ & $\begin{array}{r}-0.18 \\
(-2.95) * * *\end{array}$ & $\begin{array}{r}-0.18 \\
(-2.70)^{* * * *}\end{array}$ & $\begin{array}{r}-0.27 \\
(-3.21)^{* * *}\end{array}$ \\
\hline$L Q S E R V_{01}$ & $\begin{array}{r}16.78 \\
(3.81)^{* * * *}\end{array}$ & $\begin{array}{r}8.24 \\
(4.37)^{* * *}\end{array}$ & $\begin{array}{r}20.67 \\
(4.94)^{* * *}\end{array}$ & $\begin{array}{r}22.98 \\
(3.76) * * *\end{array}$ \\
\hline CAPITAL & $\begin{array}{r}37.80 \\
(2.00) * *\end{array}$ & $\begin{array}{r}57.70 \\
(3.08) * * *\end{array}$ & $\begin{array}{r}41.06 \\
(1.94)^{*}\end{array}$ & $\begin{array}{l}36.41 \\
(1.39)\end{array}$ \\
\hline$O C U P \%_{01}$ & $\begin{array}{r}271.67 \\
(2.32)^{* *}\end{array}$ & $\begin{array}{r}270.12 \\
(2.32)^{* * *}\end{array}$ & $\begin{array}{r}147.50 \\
(1.12)\end{array}$ & $\begin{array}{r}142.24 \\
(0.88)\end{array}$ \\
\hline UNEM\% 01 & $\begin{array}{r}6.38 \\
(3.64) * * *\end{array}$ & $\begin{array}{r}6.95 \\
(3.99) * * *\end{array}$ & $\begin{array}{r}5.13 \\
(2.61)^{* * * *}\end{array}$ & $\begin{array}{r}8.42 \\
(3.46)^{* * *}\end{array}$ \\
\hline DENSITY $_{01}$ & $\begin{array}{r}-16.87 \\
(-6.01)^{* * *}\end{array}$ & $\begin{array}{r}-17.73 \\
(-6.35)^{* * * *}\end{array}$ & $\begin{array}{r}-21.48 \\
(-6.82)^{* * *}\end{array}$ & $\begin{array}{r}-22.82 \\
(-5.86)^{* * *}\end{array}$ \\
\hline FOREIN\%OI & $\begin{array}{r}395.85 \\
(3.74)^{* * * *}\end{array}$ & $\begin{array}{r}274.21 \\
(2.61)^{* *}\end{array}$ & $\begin{array}{r}442.08 \\
(3.72)^{* * *}\end{array}$ & $\begin{array}{r}593.25 \\
(4.04)^{* * * *}\end{array}$ \\
\hline$D_{I S T M A} A_{0 I}$ & $\begin{array}{r}-18.97 \\
(-3.52)^{* * *}\end{array}$ & $\begin{array}{r}-13.92 \\
(-2.60)^{* * *}\end{array}$ & $\begin{array}{r}-13.84 \\
(-2.10)^{* *}\end{array}$ & $\begin{array}{r}-19.39 \\
(-2.60) * *\end{array}$ \\
\hline EASTING & $\begin{array}{r}9.49 \\
(3.63)^{* * * *}\end{array}$ & $\begin{array}{r}10.15 \\
(3.91)^{* * *}\end{array}$ & $\begin{array}{r}11.20 \\
(3.82)^{* * * *}\end{array}$ & $\begin{array}{r}8.76 \\
(2.42)^{* *}\end{array}$ \\
\hline COAST & $\begin{array}{r}73.99 \\
(5.79)^{* * * *}\end{array}$ & $\begin{array}{r}54.78 \\
(4.31) * * *\end{array}$ & $\begin{array}{r}62.02 \\
(4.32)^{* * * *}\end{array}$ & $\begin{array}{r}83.35 \\
(4.70)^{* * *}\end{array}$ \\
\hline Ajusted $\mathrm{R}^{2}$ & 0.42 & & & \\
\hline Pseudo $\mathrm{R}^{2}$ & & 0.26 & 0.28 & 0.29 \\
\hline F-Change & 37.07 & & & \\
\hline
\end{tabular}

Note: $*, * *$ and $* * *$ represent estimates significantly different from zero at $10 \%, 5 \%$ and $1 \%$, respectively.

(a) To overcome any possible autocorrelation and heteroskedasticity in the error terms in the models, a Heteroskedasticity and Autocorrelation Consistent estimator is used to provide a robust estimation of the covariance matrix of the parameters of a regression-type model. 
Table 5. OLS and QR estimates calculating the local fiscal burden with indirect taxes ${ }^{(a)}$

\begin{tabular}{|c|c|c|c|c|}
\hline & $\mathrm{OIC}$ & & QR & \\
\hline & הע & 0.25 & 0.50 & 0.75 \\
\hline Constant & $\begin{array}{r}-31.14 \\
(-1.69)^{*}\end{array}$ & $\begin{array}{r}-1.16 \\
(-0.11)\end{array}$ & $\begin{array}{l}-15.55 \\
(-0.99)\end{array}$ & $\begin{array}{l}-23.84 \\
(-1.09)\end{array}$ \\
\hline$U S I_{0 I}$ & $\begin{array}{r}0.31 \\
(3.88) * * * \\
\end{array}$ & $\begin{array}{r}-0.04 \\
(-0.90)\end{array}$ & $\begin{array}{r}0.17 \\
(2.41)^{* *}\end{array}$ & $\begin{array}{r}0.34 \\
(3.44)^{* * *}\end{array}$ \\
\hline$S O C E C I_{01}$ & $\begin{array}{r}6.02 \\
(0.38)\end{array}$ & $\begin{array}{r}-7.81 \\
(-0.86)\end{array}$ & $\begin{array}{r}-7.99 \\
(-0.59)\end{array}$ & $\begin{array}{r}-4.27 \\
(0.23)\end{array}$ \\
\hline$S P E C I_{01}$ & $\begin{array}{r}1.17 \\
(1.13)\end{array}$ & $\begin{array}{r}-0.01 \\
(-0.01)\end{array}$ & $\begin{array}{r}-0.17 \\
(-0.19)\end{array}$ & $\begin{array}{r}0.05 \\
(0.04)\end{array}$ \\
\hline${ }_{L Q P R I M_{01}}$ & $\begin{array}{r}-0.03 \\
(-2.55)^{*}\end{array}$ & $\begin{array}{r}-0.05 \\
(-0.96)\end{array}$ & $\begin{array}{r}-0.16 \\
(-1.94)^{*}\end{array}$ & $\begin{array}{r}-0.03 \\
(-2.88)^{* * *}\end{array}$ \\
\hline$L Q S E R V_{01}$ & $\begin{array}{r}1.97 \\
(2.70)^{* * * *}\end{array}$ & $\begin{array}{r}1.45 \\
(3.49)^{* * * *}\end{array}$ & $\begin{array}{r}2.19 \\
(3.52)^{* * *}\end{array}$ & $\begin{array}{r}3.95 \\
(4.56)^{* * * *}\end{array}$ \\
\hline CAPITAL & $\begin{array}{r}14.96 \\
(4.77)^{* * * *}\end{array}$ & $\begin{array}{r}22.88 \\
(12.77)^{* * *}\end{array}$ & $\begin{array}{r}17.22 \\
(6.65)^{* *}\end{array}$ & $\begin{array}{r}12.41 \\
(3.34)^{* *}\end{array}$ \\
\hline$O C U P \%_{01}$ & $\begin{array}{r}31.21 \\
(1.88)^{*}\end{array}$ & $\begin{array}{l}23.26 \\
(1.01)\end{array}$ & $\begin{array}{l}24.91 \\
(1.28)\end{array}$ & $\begin{array}{l}13.79 \\
(1.24)\end{array}$ \\
\hline UNEM\%OI & $\begin{array}{r}0.57 \\
(1.97)^{* *}\end{array}$ & $\begin{array}{r}0.16 \\
(0.98)\end{array}$ & $\begin{array}{r}0.27 \\
(1.08)\end{array}$ & $\begin{array}{r}0.39 \\
(1.14)\end{array}$ \\
\hline DENSITY $_{01}$ & $\begin{array}{r}0.15 \\
(0.32)\end{array}$ & $\begin{array}{r}-0.56 \\
(-2.13) * *\end{array}$ & $\begin{array}{r}-0.18 \\
(-0.46)\end{array}$ & $\begin{array}{r}-0.42 \\
(-0.76)\end{array}$ \\
\hline FOREIN\%OI & $\begin{array}{r}5.50 \\
(0.31)\end{array}$ & $\begin{array}{r}3.33 \\
(0.33)\end{array}$ & $\begin{array}{r}2.79 \\
(0.19)\end{array}$ & $\begin{array}{l}16.38 \\
(0.79)\end{array}$ \\
\hline$D_{I S T M A} A_{0 I}$ & $\begin{array}{r}1.59 \\
(1.78)^{*}\end{array}$ & $\begin{array}{r}0.75 \\
(1.47)\end{array}$ & $\begin{array}{r}0.52 \\
(0.68)\end{array}$ & $\begin{array}{r}1.54 \\
(1.46)\end{array}$ \\
\hline EASTING & $\begin{array}{r}0.01 \\
(0.01)\end{array}$ & $\begin{array}{r}0.15 \\
(0.63)\end{array}$ & $\begin{array}{r}-0.46 \\
(1.26)\end{array}$ & $\begin{array}{r}0.53 \\
(1.04)\end{array}$ \\
\hline COAST & $\begin{array}{r}1.22 \\
(0.58)\end{array}$ & $\begin{array}{r}-0.09 \\
(-0.07)\end{array}$ & $\begin{array}{r}1.85 \\
(1.02)\end{array}$ & $\begin{array}{r}0.01 \\
(0.01)\end{array}$ \\
\hline Ajusted $\mathrm{R}^{2}$ & 0.11 & & & \\
\hline Pseudo $\mathrm{R}^{2}$ & & 0.10 & 0.13 & 0.13 \\
\hline F-Change & 7.24 & & & \\
\hline
\end{tabular}

Note: $*, * *$ and $* * *$ represent estimates significantly different from zero at $10 \%, 5 \%$ and $1 \%$, respectively.

(a) To overcome any possible autocorrelation and heteroskedasticity in the error terms in the models, a Heteroskedasticity and Autocorrelation Consistent estimator is used to provide a robust estimation of the covariance matrix of the parameters of a regression-type model. 
Figure 2. Effect of urban sprawl index along the conditional distribution of local fiscal burden

(a) Effect using total local fiscal burden

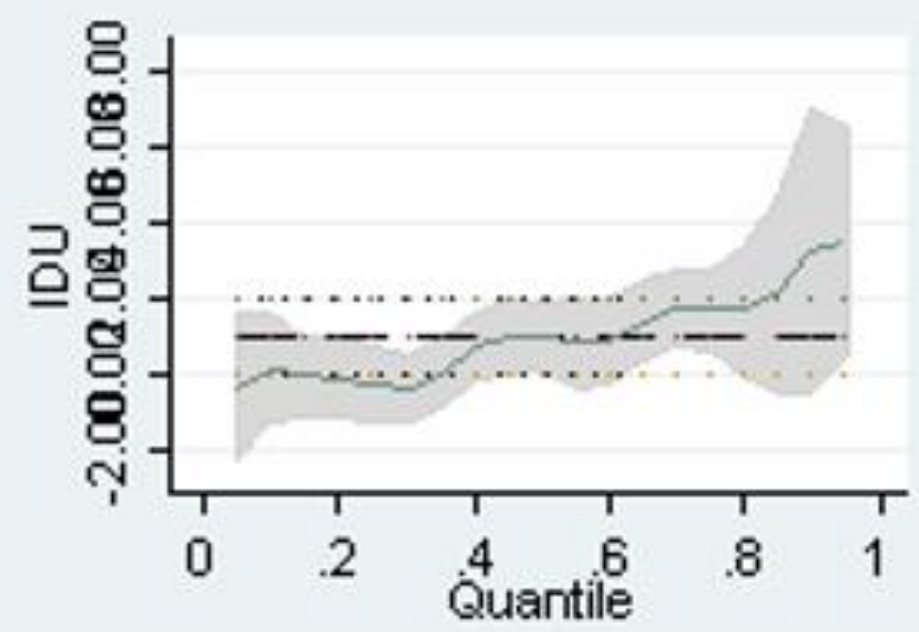

(b) Effect using only local direct taxes

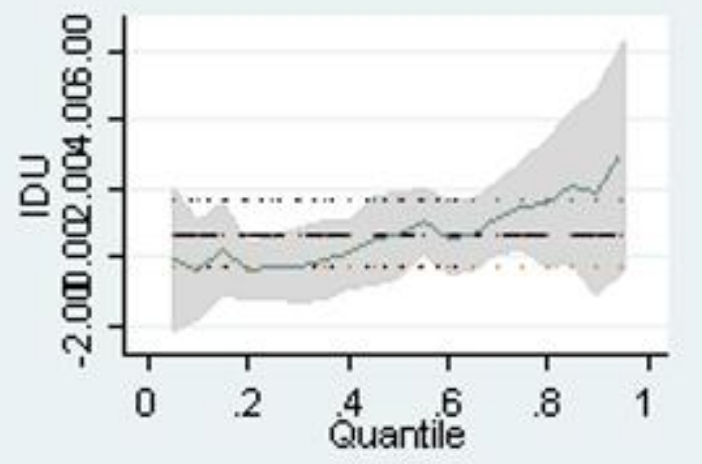

(c) Effect using only local indirect taxes

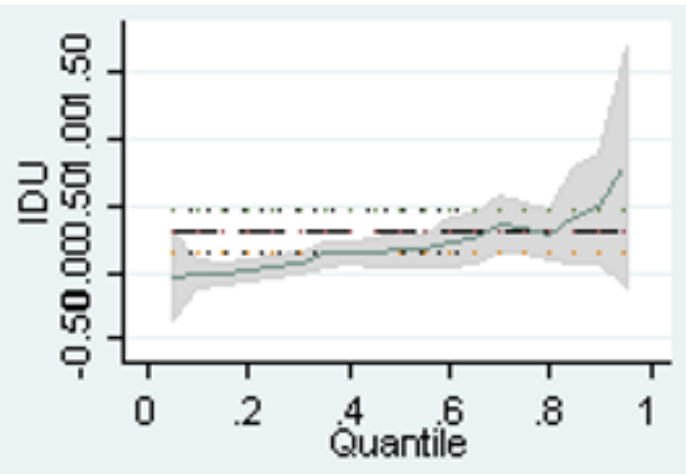

